\title{
Destruction in Sierra Leone
}

\author{
R. H. G. Lowes
}

The Sierra Leone Government has plans for wildlife protection and conservation. But meanwhile the hunting slaughter and habitat destruction go on. One result of killing off leopards, civet cats and pythons was a plague of the giant cane rat which is doing immense damage to crops.

Sierra Leone, sandwiched between Ghana and Liberia on the west coast of Africa, has, for so small a country, an astonishing variety of habitat and diversity of fauna. Unfortunately, over the past twenty years or so, agricultural and hunting pressures have been very great and in many areas the exploitation of the forest resources has changed the face of the country. But there are still considerable tracts of land more or less untouched, especially in the Northern Province where population pressure is not great, and in the east, and there are large areas of untouched mangrove swamps along the coasts, especially in the river estuaries. The Northern Province is largely hilly savanna country covered with high elephant grass, with some gallery forest along the streams and rivers and some clumps of trees, mostly acacias and African locust bean trees. The second highest mountain in West Africa is situated here (over $8,000 \mathrm{ft}$.). Cattle are grazed over most of it but not in sufficient quantities to do much damage, and wild ungulates are so scarce that there is little competition. On remote mountain slopes herds of buffalo can still be seen grazing on the short grass that grows at the higher altitude. Seasonal burning is carried out as elsewhere in Africa.

In the east and south there is still a good deal of forest especially along the Liberian border, including the Gola Forest Reserve. This very important remnant of untouched rain forest, which certainly ought to be preserved, is being exploited for timber, and big chunks of it are steadily being eaten away. All over the east and south huge areas of forest have been cut down for farming and forestry, and the big stretches of swamp in the north-west have nearly all been cultivated for rice.

At least two animals in the country urgently need the strictest protection if they are not soon to be exterminated: the pigmy hippopotamus Choeropsis liberiensis and the bald rock fowl Picathartes gymnocephalus. Both are becoming increasingly rare through loss of habitat and severe hunting pressure; a few survive in suitable remaining forest areas. Crocodiles, of which there are three species, are now rarely seen, and the rock and royal pythons are less often seen than even five years ago. The very adaptable Nile monitor is probably the commonest large reptile, but Bosc's monitor is now extremely rare.

There are still two or three small herds of elephant (the subspecific cyclotis) in the Northern Province, and their present range will come within the proposed National Park. The other fairly common large mammal, the forest buffalo or bush cow, is found in suitable localities all over the country and is not in any immediate danger.

Sierra Leone is specially rich in primates, possessing most of the 
West African species both of the forest and savanna. The two colobus monkeys are on the proposed list of prohibited animals for hunting; the others, except the green monkey and the mangabeys (which are considered vermin), are on the protected list but can be hunted on special licence. At the moment each and every species is relentlessly hunted except in certain Muslim areas of the country where it is traditional not to molest them. Chimpanzees are still fairly plentiful though ruthlessly hunted. The destruction of leopards, civet cats and pythons has resulted in an explosion of the giant cane rat population, now causing tremendous damage to rice fields and cassava plantations.

The large flocks of wildfowl and gamebirds one used to see ten years ago are now sadly diminished and even some of the migratory birds like the beautiful Senegal roller are less common; birds of prey are also vanishing from the skies. The danger to the smaller birds is the proliferation of air guns and small shot guns-everything is considered a legitimate target. There is some excuse, of course, for this trigger-happy state of affairs because of the lack of protein in the people's diet, and hunting is mainly for meat. But this will be small comfort when everything is gone. Under the British colonial government nothing was done to encourage conservation and no game laws of any consequence were made. The present position rests squarely on its shoulders.

Laws increasing the levies on live animal exports have recently been enacted, and these should help to stop the drain to some extent, especially in chimpanzees. But with a few exceptions, notably the pigmy hippo and the bald rock fowl, any animal can be exported under licence. No conservation measures have been put into force and there are no active game laws. A start was attempted in 1967 when a Wildlife Branch was established in the Forestry Division, and the government appointed a Game Superintendent who was sent to the Mweka School in Tanzania for training. A Wildlife Conservation Act was drawn up but has not yet been made law. This allows for the creation of one national park in the north, Quatamba, and one large game reserve, Kilimi, and the conversion into game reserves, 'partly or wholly'; of five existing forest reserves; reserves are also planned on the estuaries and mangrove islands in the Bonthe district and Lake Sonfon (for wildfowl). The Game Superintendent, Mr D. Elliott, has plans for at least two more strict reserves, one of which would protect the manatee, still occurring in the maze of creeks and waterways between the mouths of the Sewa and Pampana rivers.

NOTE. Since this article was put intype, the author has written to say that the Government is now taking steps to put the 1967 Wildlife Conservation Act into effect. The boundaries of three new reserves are being demarcated: Quatamba (285 square miles), Kilimi (I 50 square miles), and Lake Sonfon (six miles by two); several forest reserves have been created where no hunting will be allowed; $£ 6000$ has been allocated to the Game Department, and rifles issued to the rangers. Mr Sawyer, Chief Conservator of Forests and head of the Game Department, and a very keen conservationist, has returned from the USA. 